\title{
Studies on Substitution of Inorganic Fertilizers for Organic and Biological Fertilizers in Ashwagandha (Withania somnifera Dunal.) Production
}

\author{
R. Praveen ${ }^{1 *}$, N. Hari Prasad Rao ${ }^{2}$ and G. Sathyanarayana Reddy ${ }^{3}$ \\ ${ }^{1}$ College of Horticulture, Venkataramannagudem, Dr Y.S.R Horticultural University, \\ Andhra Pradesh, India \\ ${ }^{2}$ College of Horticulture, Rajendranagar, Dr Y.S.R Horticultural University, \\ Andhra Pradesh, India \\ ${ }^{3}$ Herbal garden, Rajendranagar, Dr Y.S.R Horticultural University, Andhra Pradesh, India \\ *Corresponding author
}

\section{Keywords}

Yield, Quality,

Economics,

Alkaloids, Green

manure

Article Info

Accepted:

15 March 2019

Available Online:

10 April 2019

\section{A B S T R A C T}

A field experiment was conducted at College of Horticulture, Venkataramannagudem, West Godavari district, Andhra Pradesh during late kharif season of 2010 with an objective to evaluate the package of organic and biological sources of nutrients vis-à-vis inorganic fertilizers on yield, quality and economics of ashwagandha. The experiment was laid out in randomized block design with fourteen treatments replicated thrice. The treatments consisted of nutrients from different organic sources Viz., Neem cake, vermicompost, poultry manure, farm yard manure, sunnhemp in situ green manure, biological sources viz., Azospirillum + PSB alone and in combination with organic sources of nutrients and inorganic sources viz., recommended dose of fertilizers (N P K at 40:60:20 $\mathrm{kg} \mathrm{ha}^{-1}$ ) and $50 \%$ recommended dose of fertilizers (N P K at 20:30:10 $\mathrm{kg} \mathrm{ha}^{-1}$ ). The study revealed that application of Poultry manure + Biofertilizers (Azospirillum + PSB) produced longest roots $(21.00 \mathrm{~cm})$ with widest diameter $(1.59 \mathrm{~cm})$ but was on par with vermicompost + biofertilizers and recommended dose of inorganic fertilizers. The same treatment i.e., Poultry manure + Biofertilizers recorded maximum fresh root $(1524 \mathrm{~kg}$ $\left.\mathrm{ha}^{-1}\right)$, dry root $\left(739 \mathrm{Kg} \mathrm{ha}^{-1}\right)$ and seed yield $\left(186.4 \mathrm{~kg} \mathrm{ha}^{-1}\right)$ but was on par with vermicompost + biofertilizers and recommended dose of inorganic fertilizers. Similar trend was observed in respect of total alkaloid content of roots. The treatment poultry manure + Biofertilizers also recorded maximum gross (Rs 96,202) and net income (Rs 72,252) but B:C ratio was maximum in recommended dose of fertilizers (3.12) followed by Poultry manure + Biofertilizers. Thus, Poultry manure + Biofertilizers with overall better performance and economic advantage over other treatments can be recommended for complete substitution of inorganic fertilizers in ashwagandha.

\section{Introduction}

Ashwagandha (Withania somnifera Dunal.) popularly known as "Indian ginseng" is an important cultivated medicinal plant of India. The root of the plant is mainly used in ayurvedic and unani preparations. The pharmacological activity of roots is attributed 
to the presence of alkaloids with anine and somniferine. It is used as an antistress, immunomodulatory, anticancer, antioxidant, anti arthritic, antidepressant, diuretic, hypocholestraemic and adaptogenic. In the last 40-50 years farmers are heavily dependence on inorganic fertilizers to maximize crop yields resulted in negative change in soil physical and chemical properties. In the changing scenario, the technology based primarily on continuous use of chemical inputs with only a meagre supplementation of organic manures is thought to be not sustainable since the productivity of soils is fast deteriorating. In international trade, the herbal medicines and products produced through organic forms command premium price and in much demand. Therefore, farmers are searching for alternatives to replace the chemical fertilizers by production and use of organic manures and biofertilizers. Since, very limited systematic research efforts have been made to optimize the organic sources of nutrients to enhance the productivity and quality, the present experiment was carried out to study the productivity, quality and economics of ashwagandha as influenced by organic and bionutrition.

\section{Materials and Methods}

A field experiment was conducted during late Kharif season of 2010 at College of Horticulture, Venkataramannagudem, West Godavari Dist (Andhra Pradesh) under irrigated conditions. The soil of the experimental site was sandy loam in texture, neutral in reaction, low in organic carbon, low in available nitrogen (192 kg/ha), high in available phosphorus (28.5 $\mathrm{kg} / \mathrm{ha})$ and medium in available potassium $(255 \mathrm{~kg} / \mathrm{ha})$. The studies were carried out using ashwagandha cv. Poshita with 14 treatments viz., neem cake $4 \mathrm{t} \mathrm{ha}^{-1}$ (NC $\left.4 \mathrm{t} \mathrm{ha}^{-1}: \mathrm{T}_{1}\right)$, vermicompost $5 \mathrm{t} \mathrm{ha} \mathrm{ha}^{-1}\left(\mathrm{VC} \quad \mathrm{t} \mathrm{ha} \mathrm{ha}^{-1} \mathrm{~T}_{2}\right)$, poultry manure $5 \mathrm{t} \mathrm{ha}^{-1}$ (PM $\left.5 \mathrm{t} \mathrm{ha}^{-1}: \mathrm{T}_{3}\right)$, farm yard manure $12 \mathrm{t} \mathrm{ha}^{-1}$ (FYM $12 \mathrm{t} \mathrm{ha}^{-1:} \mathrm{T}_{4}$ ), insitu green manuring with sunnhemp (GM: $\left.\mathrm{T}_{5}\right), \mathrm{NC} 4 \mathrm{t} \mathrm{ha}^{-1}+\mathrm{BF}\left(\mathrm{T}_{6}\right), \mathrm{VC} 5 \mathrm{t} \mathrm{ha}^{-1}+\mathrm{BF}$ $\left(\mathrm{T}_{7}\right)$, PM $5 \mathrm{t} \mathrm{ha}^{-1}+\mathrm{BF}\left(\mathrm{T}_{8}\right)$, FYM $12 \mathrm{t} \mathrm{ha}^{-1}+$ $\mathrm{BF}\left(\mathrm{T}_{9}\right), \mathrm{GM}+\mathrm{BF}\left(\mathrm{T}_{10}\right)$, bio-fertilizers consisting of Azospirillum and Phosphate solubilizing bacteria (BF: $\mathrm{T}_{11}$ ), recommended dose of fertilizers (RDF: $T_{12}$ ), 50 per cent recommended dose of fertilizers (50 per cent RDF: $\left.\mathrm{T}_{13}\right)$ and control $\left(\mathrm{T}_{14}\right)$. The experiment was laid out in a randomized block design with three replications. Sunnhemp seeds were broadcasted at $40 \mathrm{~kg} \mathrm{ha}^{-1}$ and it was incorporated at the age of 53 days by tractor drawn rotavator and left for ten days to decompose. The organic manures were applied as per the treatments and incorporated into the soil a week before seed sowing. The biofertilizers Azospirillum lipoferum (strain ICM 1001) and phosphate solubilising bacteria (Bacillus meghatherium var phosphaticum)@ $5 \mathrm{~kg} \mathrm{ha}^{-1}$ each were soil and seed inoculated. The crop was sown at $30 x 10 \mathrm{~cm}$ spacing. The crop was sprayed with neem oil @ $4 \mathrm{ml}$ per litre against leaf eating insects. The crop was harvested at 180 DAS. Data were recorded on root length and root diameter per plant in $\mathrm{cm}$ from randomly selected five plants from each replication. The plants from each net plot were uprooted at harvest the roots were separated and dried under sun. The fresh and dry root yield was recorded and expressed in $\mathrm{kg}$ per hectare. Total Alkaloid content was estimated by using method given by Mishra, 1989. The prices of all the inputs, labour cost, dry root yield and seed yield that were prevailing at the time of their use were taken into consideration for calculating cost of cultivation, gross income, net income and benefit: cost ratio. The data collected were statistically analysed for interpretation following the procedure outlined by Panse and Sukhatme (1970). 


\section{Results and Discussion}

The main yield attributes in ashwagandha are root length and root diameter. The results indicated that application of PM $5 \mathrm{tha}^{-1}+\mathrm{BF}$ produced the longest roots $(21.00 \mathrm{~cm})$ with widest diameter $(1.59 \mathrm{~cm})$ but was on par with VC $5 \mathrm{t} \mathrm{ha}^{-1}+\mathrm{BF}$ and RDF (Table 1). The higher values of yield attributes of ashwagandha were mainly due to better growth of the plant which can be related to higher values of growth parameters recorded at harvest. The results corroborate the findings of Jayalakshmi (2003) in coleus.

\section{Root yield and quality}

At harvest, the combination of PM $5 \mathrm{tha}^{-1}+$ $\mathrm{BF}$ produced the highest fresh root yield $\left(1524 \mathrm{~kg} \mathrm{ha}^{-1}\right)$, dry root yield $\left(739 \mathrm{~kg} \mathrm{ha}^{-1}\right)$, alkaloid content $(0.33 \%)$ and alkaloid yield $\left(2.45 \mathrm{~kg} \mathrm{ha}^{-1}\right)$ but was on par with VC $5 \mathrm{t} \mathrm{ha}^{-1}$ $+\mathrm{BF}$ and RDF (Table 1). The maximum root yield observed in the plants may possibly be due to increased length and diameter of roots. The increase in fresh and dry root yield may be attributed to availability of more nutrients continuously through poultry manure over a long period and biofertilizer inoculation thus favouring the growth and development of better root system resulting in better uptake of nutrients. Similar results were also reported with poultry manure + Azospirillum $(2 \mathrm{~kg} / \mathrm{ha})$ + phosphobacteria (2 $\mathrm{kg} / \mathrm{ha})$ in Bhumyamalaki (Chezhiyan et al., 2003). The alkaloids being the products of nitrogen metabolism, the production of alkaloids is directly related to nitrogen supply to the plants. Thus higher availability of nitrogen through poultry manure, vermicompost and Azospirillum might have played an important role in biosynthesis and accumulation of alkaloid (Waller and Nowacki, 1978). Similar results were reported by Vijayabharati (2002) in ashwagandha. Further the same treatments had also recorded higher total alkaloid yield per ha and were on par with each other. The higher total alkaloid yield was attributed to higher total alkaloid content in roots and higher root yield of ashwagandha. The treatments, PM $5 \mathrm{t} \mathrm{ha}^{-1}+\mathrm{BF}$ had recorded yield attributes, yield and alkaloid content on par with VC $5 \mathrm{tha}^{-1}+\mathrm{BF}$ and RDF indicating the scope for complete substitution of inorganic fertilizers with these treatments in ashwagandha. Similar findings were also reported by Vennila et al., (2008) in coleus and Haruna et al., (2009) in roselle.

The organic treatments with a combination of biofertilizers Viz., NC + BF, VC + BF, PM + $\mathrm{BF}, \mathrm{FYM}+\mathrm{BF}$ and $\mathrm{GM}+\mathrm{BF}$ had recorded yield attributes, yield and quality parameters significantly higher than organic treatments (NC, PM, VC, FYM and GM) alone indicating the need of biofertilizers for improving yield attributes and yield. Similar findings with combination of Vermicompost and biofertilizers in mint (Suresh et al., 2008), poultry manure and biofertilizers in Bhumyamalaki (Chezhiyan et al., 2003), neem cake and biofertilizers in Brassica juncea (Irfan Khan et al., 2010), FYM and biofertilizers in turmeric (Mohapatra and Das 2009), green manuring and biofertilizers in senna (Rao, 2008) were also reported.

Further, the treatment with Azospirillum + PSB (BF) had recorded yield attributes and yields on par with 50 per cent RDF offering an opportunity of reducing inorganic fertilizers by 50 per cent with the inoculation of these biofertilizers in ashwagandha.

The synergistic interaction among the inoculated microbes might have enhanced the activity of nitrogen fixation, phophorus availability and production of growth promoting substances (Anandan, 2000) leading to the fresh and dry root yields on par with 50 percent RDF. Gopal and Paramaguru (2006) in senna also reported similar findings. 
Table.1 Root yield attributes, root yield parameters and quality parameters as influenced by organic manures and their combination with biofertilizers in ashwagandha

\begin{tabular}{|c|c|c|c|c|c|c|}
\hline Treatments & $\begin{array}{l}\text { Root length } \\
(\mathrm{cm})\end{array}$ & $\begin{array}{l}\text { Root Diameter } \\
(\mathrm{cm})\end{array}$ & $\begin{array}{l}\text { Fresh root yield (kg } \\
\left.\mathrm{ha}^{-1}\right)\end{array}$ & $\begin{array}{l}\text { Dry root yield } \\
\left(\mathrm{kg} \mathrm{ha}^{-1}\right)\end{array}$ & $\begin{array}{l}\text { Alkaloid } \\
\text { content (\%) }\end{array}$ & $\begin{array}{l}\text { Alkaloid yield } \\
\left(\mathrm{Kg} \mathrm{ha}^{-1}\right)\end{array}$ \\
\hline T1: NC 4 t ha $^{-1}$ & 16.12 & 1.07 & 1150 & 540 & 0.28 & 1.55 \\
\hline $\mathrm{T}_{2}:$ VC 5 t ha ${ }^{-1}$ & 17.40 & 1.20 & 1247 & 592 & 0.29 & 1.74 \\
\hline $\mathrm{T}_{3}:$ PM $5 \mathrm{t} \mathrm{ha}^{-1}$ & 17.56 & 1.24 & 1289 & 612 & 0.29 & 1.78 \\
\hline $\mathrm{T}_{4}:$ FM 12t ha ${ }^{-1}$ & 16.10 & 1.05 & 1134 & 532 & 0.28 & 1.52 \\
\hline $\mathbf{T}_{5}: \mathbf{G M}$ & 15.86 & 1.04 & 1121 & 526 & 0.27 & 1.42 \\
\hline $\mathrm{T}_{6}:$ Neem cake $4 \mathrm{t} \mathrm{ha}^{-1}+\mathrm{BF}$ & 19.03 & 1.32 & 1411 & 677 & 0.29 & 2.00 \\
\hline $\mathbf{T}_{7}:$ vermicompost $5 \mathrm{t} \mathrm{ha}^{-1}+\mathrm{BF}$ & 20.70 & 1.52 & 1484 & 719 & 0.33 & 2.37 \\
\hline $\mathrm{T}_{8}:$ Poultry manure $5 \mathrm{t} \mathrm{ha}^{-1}+\mathrm{BF}$ & 21.00 & 1.59 & 1524 & 739 & 0.33 & 2.45 \\
\hline $\mathrm{T}_{9}:$ Farm yard manure $12 \mathrm{t} \mathrm{ha}^{-1}+\mathrm{BF}$ & 18.76 & 1.29 & 1348 & 647 & 0.29 & 1.90 \\
\hline $\mathrm{T}_{11}$ : Azospirillum $5 \mathrm{~kg} \mathrm{ha}^{-1}+$ PSB $5 \mathrm{~kg} \mathrm{ha}^{-1}(\mathrm{BF})$ & 14.20 & 0.83 & 1049 & 487 & 0.23 & 1.12 \\
\hline $\mathrm{T}_{12}: 100 \% \mathrm{RDF}$ & 20.00 & 1.48 & 1473 & 714 & 0.31 & 2.21 \\
\hline $\mathrm{T}_{13}: \mathbf{5 0 \%} \mathrm{RDF}$ & 14.73 & 0.89 & 1054 & 490 & 0.23 & 1.15 \\
\hline$T_{14}:$ Absolute control & 13.13 & 0.71 & 0984 & 447 & 0.20 & 0.89 \\
\hline Mean & 17.36 & 1.17 & 1254.5 & 595.92 & 0.278 & 1.700 \\
\hline SEm \pm & 0.430 & 0.05 & 21.00 & 9.50 & 0.015 & 0.090 \\
\hline CD (0.05) & 1.260 & 0.14 & 62.00 & 27.8 & 0.030 & 0.250 \\
\hline
\end{tabular}


Table. 2 Cost of cultivation $\left(\mathrm{Rs} \mathrm{ha}^{-1}\right)$, gross income $\left(\mathrm{Rs} \mathrm{ha}^{-1}\right)$, net income ( $\mathrm{Rs} \mathrm{ha}^{-1}$ ) and benefit cost ratio (BCR) as influenced by different organic manures and their combination with biofertilizers in ashwagandha

\begin{tabular}{|c|c|c|c|c|c|c|c|c|}
\hline Treatments & $\begin{array}{l}\text { Root yield } \\
\left(K^{\prime} \text { ha }^{-1}\right)\end{array}$ & $\begin{array}{l}\text { Cost of root } \\
\text { yield }\left(\text { Rs ha }^{-1}\right)\end{array}$ & $\begin{array}{l}\text { Seed yield (Kg } \\
\left.\text { ha }^{-1}\right)\end{array}$ & $\begin{array}{c}\text { Cost of Seed (Rs } \\
\left.\text { ha }^{-1}\right)\end{array}$ & $\begin{array}{c}\text { Cost of } \\
\text { production (Rs) }\end{array}$ & $\begin{array}{l}\text { Gross income } \\
\quad \text { (Rs) }\end{array}$ & Net income (Rs) & B:C ratio \\
\hline T1: NC 4 t ha ${ }^{-1}$ & 540 & 59400 & 154.60 & 12368 & 34450 & 71768 & 37318 & 1.08 \\
\hline$T_{2}: \operatorname{VC} 5 \mathrm{tha}^{-1}$ & 592 & 65120 & 159.16 & 12733 & 32950 & 77853 & 44903 & 1.36 \\
\hline $\mathrm{T}_{3}:$ PM $5 \mathrm{t} \mathrm{ha}^{-1}$ & 612 & 67320 & 160.43 & 12834 & 23450 & 80154 & 56704 & 2.42 \\
\hline$T_{4}:$ FM 12t ha ${ }^{-1}$ & 532 & 58520 & 143.30 & 11464 & 26450 & 69984 & 43534 & 1.64 \\
\hline $\mathrm{T}_{5}: \mathbf{G M}$ & 526 & 57860 & 141.26 & 11301 & 23150 & 69161 & 46011 & 1.99 \\
\hline $\begin{array}{c}\mathrm{T}_{6}: \text { Neem cake } 4 \mathrm{t} \mathrm{ha}^{-1} \\
+\mathrm{BF}\end{array}$ & 677 & 74470 & 176.36 & 14109 & 34950 & 88579 & 53629 & 1.53 \\
\hline $\begin{array}{c}T_{7}: \text { vermicompost } 5 t \\
h^{-1}+B F\end{array}$ & 719 & 79090 & 184.60 & 14768 & 33450 & 93858 & 60408 & 1.80 \\
\hline $\begin{array}{c}T_{8}: \text { Poultry manure } 5 t \\
h a^{-1}+B F\end{array}$ & 739 & 81290 & 186.40 & 14912 & 23950 & 96202 & 72252 & 3.02 \\
\hline $\begin{array}{c}\mathrm{T}_{9} \text { : Farm yard manure } \\
12 \mathrm{th} \mathrm{ha}^{-1}+\mathrm{BF}\end{array}$ & 647 & 71170 & 174.40 & 13952 & 26950 & 85122 & 58172 & 2.16 \\
\hline $\begin{array}{r}\mathrm{T}_{10}: \text { Green manure } \\
(\text { Crotolaria } \\
\text { juncea })+\mathrm{BF}\end{array}$ & 621 & 68310 & 171.50 & 13720 & 23650 & 82030 & 58380 & 2.47 \\
\hline $\begin{array}{r}\mathrm{T}_{11} \text { : Azospirillum } 5 \mathrm{~kg} \\
\mathrm{ha}^{-1}+\text { PSB } 5 \\
\mathrm{~kg} \mathrm{ha}^{-1}(\mathrm{BF})\end{array}$ & 487 & 53570 & 134.60 & 10768 & 20950 & 64338 & 43388 & 2.07 \\
\hline $\mathrm{T}_{12}: \mathbf{1 0 0 \%} \mathrm{RDF}$ & 714 & 78540 & 183.36 & 14669 & 22607 & 93209 & 70602 & 3.12 \\
\hline $\mathrm{T}_{13}: \mathbf{5 0 \%} \mathrm{RDF}$ & 490 & 53900 & 135.03 & 10802 & 21528 & 64702 & 43174 & 2.00 \\
\hline$T_{14}$ : Absolute control & 447 & 49170 & 113.60 & 9088 & 20450 & 58258 & 37808 & 1.85 \\
\hline
\end{tabular}

Note: Cost of Dry root @ Rs 110 per kg and Seed @ Rs 80 per kg. 
The yield attributes, yield and quality parameters recorded with control were, however, the lowest at harvest.

\section{Economics}

Higher gross income were obtained with the treatments, PM $5 \mathrm{t} \mathrm{ha}^{-1}+\mathrm{BF}$ (Rs 96202/-) and VC $5 \mathrm{t} \mathrm{ha}^{-1}+\mathrm{BF}$ (Rs 93858/-) compared to RDF (Rs 93209/-) owing to higher yield recorded with the treatments (Table 2). Further the treatments with neem cake component were observed with higher cost of cultivation owing to high cost of neem cake resulting in lower net income and BCR. The treatment, RDF had recorded the maximum BCR (3.12) followed by PM $5 \mathrm{t} \mathrm{ha}^{-1}+\mathrm{BF}$ (3.02) and GM + BF (2.47).

In conclusion, the treatment, poultry manure 5 $\mathrm{t} \mathrm{ha}^{-1}+\mathrm{BF}$ with overall better performance and economic advantage over other organic treatments can be recommended for complete substitution of inorganic fertilizers in ashwagandha. The treatment, biofertilizers containing Azospirillum and PSB can be recommended for reducing quantity of inorganic fertilizers and also to improve soil biological properties.

\section{Acknowledgment}

Thanks to my chairman Dr. N. Hari Prasad Rao and Dr. D.V. Swami for their inspiring guidance, valuable and technical advice.

\section{References}

Anandan, M 2000 An integrated approach of biofertilizer for sustainable agriculture. Intensive Agriculture 38 (1-2): 9-11.

Chezhiyan, N., Saraswathy, S. and Vasumathi, R. 2003. Studies on organic manures, biofertilizers and plant density on growth, yield and alkaloid content of Bhumyamalaki (Phyllanthus amarus Schum. and Tonn.). South Indian Hort. 51: 16.

Gopal, N O and Paramaguru P 2006 Synergistic interaction of Azospirillum and phosphorus solubilizing bacteria for enhancing the growth, yield and rhizosphere microbial dynamics of the senna (Cassia angustifolia Vahl.). In: Book of abstracts on International conference on Globalization of Traditional, Complementary and Alternative Systems of Medicine, TNAU, Coimbatore, March 16-18, Poster abstract, 25:28.

Haruna, Ibrahim, I. M. and Rahman, H. S. A. 2009. The yield and profitability of roselle (Hibiscus sabdariffa L.) at varying poultry manure and nitrogen fertilizer rates in the Southern guinea Savanna of Nigeria. Electronic J. Environmental Agri. Food chemistry. 8: 11, 1136-1139.

Irfan khan, aquil Ahmed, Anwar and Masood. 2010. Effect of Azospirillum inoculation and organic manures on Brassica juncea (L.) Czern and Coss. Intl. J. Plant. Sci. 5: 2, 699-671.

Jayalakshmi, S. 2003. Effect of spacing and nitrogen levels on growth, tuberous root yield and alkaloid content of medicinal coleus (Coleus forskohlii Brig.). M.Sc. Thesis, Tamil Nadu Agricultural University, Coimbatore.

Mishra, S. N. 1989. Analytical methods for analysis of total alkaloids in roots of Withania spp. Proc. All India Workshop on Medicinal and Aromatic plants. Faizabad, 4-7 December. P. 492-495.

Mohapatra, S. C. and Das, T. K. 2009. Integrated effect of biofertilizers and organic manures on turmeric (curcuma longa). Environment and Ecology. 27:3, 1444-1445.

Panse, V G and Sukhatme P V 1978 
Statistical methods for agricultural workers. Indian Council of Agricultural Research, New Delhi. pp: 359.

Rao, H. P. N. 2008. Studies on the effect of organic and bionutrient sources on growth, yield and quality in senna (Cassia angustifolia Vahl.) and their residual effect on succeeding roselle (Hibiscus sabdariffa L.) crop. Ph.D. Thesis, Acharya N. G. Ranga Agriculturral University, Hyderabad.

Suresh, M., Sridevi, P. and Ashok, L. 2008. Effect of vermicompost, FYM and their combination with biofertilizers on Ashwagandha. Abstracts $95^{\text {th }}$
Indian Science Congress. P. 98-101. Vennila, C. and Jayanthi, C. 2008. Nutrient use pattern and available nutrient balance as influenced by sources of nutrients in medicinal Coleus. J. Farming Systems Res. Development. 14: 1, 73-77.

Vijayabharati, J. A. N. 2002. Integrated nutrient management of ashwagandha for growth, yield and quality. M.Sc. (Hort.) Thesis, Tamil Nadu Agricultural University, Madurai.

Waller, G. R. and Nowacki, E. K. 1978. Alkaloid biology and Metabolism in Plants. Plenum Press, New York.

\section{How to cite this article:}

Praveen, R., N. Hari Prasad Rao and Sathyanarayana Reddy, G. 2019. Studies on Substitution of Inorganic Fertilizers for Organic and Biological Fertilizers in Ashwagandha (Withania somnifera Dunal.) Production. Int.J.Curr.Microbiol.App.Sci. 8(04): 1893-1899.

doi: https://doi.org/10.20546/ijcmas.2019.804.222 